\title{
Reservoir sedimentation impact downstream in a semi-arid basin with greenhouses cultivation
}

\author{
Sergio Arjona ${ }^{1, *}$, Agustín Millares ${ }^{2}$, and Asunción Baquerizo ${ }^{2}$ \\ ${ }^{1}$ Andalusian Regional Government, Almería, Spain \\ ${ }^{2}$ Group of Environmental Fluid Dynamics, Andalusian Institute for Earth System Research (IISTA). \\ University of Granada, Spain
}

\begin{abstract}
This work analyzes the loss of storage, in a medium-term basis, of Beninar reservoir (Almería, Spain) built in a semiarid watershed and its consequences downstream. The reservoir, in the Adra river basin (Southern Spain), was designed to supply water for the irrigation of more than 28.000 hectares of greenhouses. Its storage volume, that was initially of $68 \mathrm{hm}^{3}$ in 1984, has been reduced approximately to half. The total sediment volume arrived to the reservoir during the last 32 years is 6,8 $\mathrm{hm}^{3}$, of which $1,68 \mathrm{hm}^{3}$ are estimated to come from fluvial contributions. The results remark the torrential nature of rainfall events for generating large sediment contributions and highlights the importance of taking into account these types of events. The total loss of storage is especially relevant from two points of view 1) reduction of flood abatement due to sedimentation and structural problems of dam, which has left only $2 \mathrm{hm}^{3}$ of regulation capacity and 2) loss of water volume which is essential to improve the water quality of the overexploited and salinized aquifers which supply the greenhouses downstream. Beninar reservoir is a key infrastructure to preserve a competitive price of water for greenhouse cultivation.
\end{abstract}

\section{Introduction}

Reservoirs are built in rivers for different objectives, such as water supply and irrigation, power regulation and flood control. Their interruption of the sediment transport along river systems [1] causes not only a progressive loss of their storage capacity but also a severe impact downstream. On average, the storage capacity of reservoirs is being lost at an annual rate of $0,5 \%$ in Spain and $1 \%$ in the world [2]. Despite the increasing demand for water storage, there are fewer environmentally and economically feasible locations to build new reservoirs, an issue that threatens the sustainability of water supply [3].

The quantification of soil loss, fluvial transport and sedimentation processes is essential for the proper management of reservoirs. This is especially important in semiarid environments, where the large amount of available sediment at the river floodplains and the occurrence of torrential precipitation events produce important damages along the river and hillslopes, and a severe reservoir siltation [4]. In semiarid mountainous areas

\footnotetext{
* Corresponding author: sergioarjona@,ciccp.es
} 
bedload fluvial processes are significant $[5,6]$ exceeding normally $50 \%$ of suspended sediment loads [7].

Almeria (south-east of Spain) supplies vegetables to Europe throughout the winter season due to intensive greenhouse horticulture production. Currently, the greenhouses area is 31.034 ha, being mainly concentrated in Campo de Dalias with 21.285 ha [8] in the delta of Adra river. The horticultural production system in south-west of Almeria mainly uses water from the Campo de Dalias aquifer, that suffers seawater intrusion problems that greatly affect the quality of irrigation water. This situation is favouring the preference for water supplied by neighbouring reservoirs that guarantee water quality for agricultural purposes [9].

Dams also contribute to laminate floods that are relatively frequent in semi-arid basins in the south-east of Spain, where it is expected that climate change produces an increase of their occurrence and intensity [10]. On the other side they may have a severe impact on the river mouth coastal zones [11-13].

The main goal of this research is to analyze the dynamics of erosion and transport processes in a mountainous semi-arid river and their effect on siltation in a reservoir, the consequent loss of storage capacity and its downstream impact. The study site is Beninar reservoir $\left(68 \mathrm{hm}^{3}\right)$, in southern Spain, where data has been gathered during 32 years of siltation processes. The information used for the analysis includes bathymetric, topographic and analytical characteristics of the sediment at different field campaigns. Results allowed to differentiate fluvial and from hillslope sediment contributions. The siltation effects downstream were also analyzed in detail taking into account the intensive exploitation by greenhouse cultivation at the coastal area. The results call into question the viability of this industry, widespread within the southeast of Spain, from water quality and availability perspective.

\section{Study site and available data}

The south-east of Spain is a rather mountainous area, with deep and narrow valleys where rainfall events are scarce but intense, with relatively short duration. Due to these characteristics their rivers may change from ephemeral to torrential. Beninar dam is located along the main course of the Adra river. Its basin covers an area of approximately $522 \mathrm{~km}^{2}$, and includes the headwaters of Yator, Nechite, Bayarcal and Alcolea rivers and its main channel, with slopes of $8 \%, 10 \%, 8 \%, 8 \%$ and $2 \%$ respectively (Fig. 1). Other characteristics of Adra river basin are summarized in Table 1.

Table 1. Characteristics of Adra river basin

\begin{tabular}{|c|c|c|c|c|c|c|c|}
\cline { 2 - 7 } \multicolumn{1}{c|}{} & $\begin{array}{c}\text { Max. } \\
\text { Temperature } \\
\left({ }^{\circ} \mathrm{C}\right)\end{array}$ & $\begin{array}{c}\text { Min. } \\
\text { Temperature } \\
\left({ }^{\circ} \mathrm{C}\right)\end{array}$ & $\begin{array}{c}\text { Daily } \\
\text { Precipitation } \\
(\mathrm{mm})\end{array}$ & $\begin{array}{c}\text { Daily } \\
\text { Evaporation } \\
(\mathrm{mm})\end{array}$ & $\begin{array}{c}\text { Contribution } \\
\left(\mathrm{m}^{3} \text { day }{ }^{-1}\right)\end{array}$ & $\begin{array}{c}\text { Water } \\
\text { supply }\left(\mathrm{m}^{3}\right. \\
\left.\text { day }^{-1}\right)\end{array}$ & $\begin{array}{c}\text { Daily Flow } \\
\left(\mathrm{m}^{3} \mathrm{~s}^{-1}\right)\end{array}$ \\
\hline Maximum & 47,10 & 30,00 & 118,50 & 15,00 & $3.623 .183,00$ & $191.200,00$ & 131,94 \\
\hline Minimum & 0,00 & $-5,00$ & 0,00 & 0,00 & 0,00 & 0,00 & 0,00 \\
\hline Average & 23,00 & 11,48 & 0,88 & 3,90 & $86.194,20$ & $28.725,91$ & 1,25 \\
\hline
\end{tabular}

The contributions of the river and the precipitation were recorded at the Darrical gauge station and the weather station on Beninar dam respectively during the whole period under analysis. Adra river, with a mean flow of $1,25 \mathrm{~m}^{3} \cdot \mathrm{s}^{-1}$, can achieve peaks of $132 \mathrm{~m}^{3} \cdot \mathrm{s}^{-1}$ during the intense events as the one of December $25^{\text {th }}, 2009$, which highlights the huge variability of flow at the study area. 


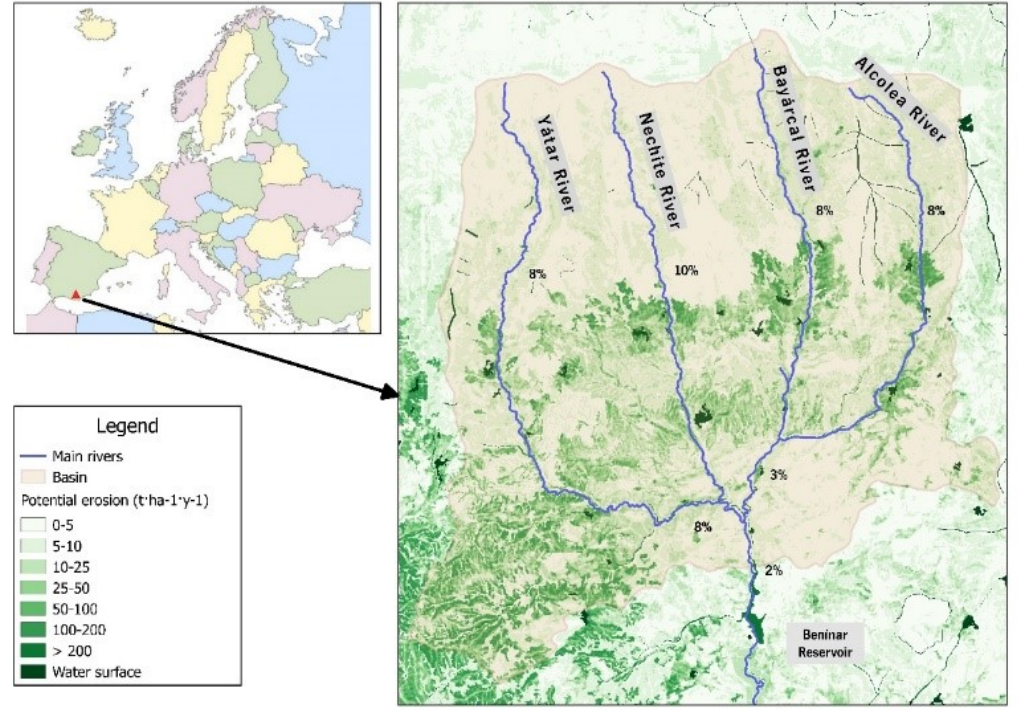

Fig.1. Location of the study basin and Beninar reservoir.

From a geologic and geomorphologic point of view, two units with different hillslope erosion dynamics can be distinguished. Most of the basin areas have moderate laminar erosion ranges (1-25 tha hi $\left.\mathrm{y}^{-1}\right)$ estimated with RUSLE approaches [14]. The west part of the basin is influenced by the presence of the Sierra de la Contraviesa with intense erosive processes and associated soil loss that can exceed $200 \mathrm{t} \mathrm{ha}^{-1} \mathrm{y}^{-1}[15]$.

One of the main goals of the construction of Beninar dam was to prevent floods downstream, after the October 1973 extreme event. During two days, on October $18^{\text {th }}$ and $19^{\text {th }}$ the south-east of Iberian Peninsula suffered an intense rain event, producing severe damage to goods and more than 80 dead people [16]. The initial storage volume of Beninar was $68,12 \mathrm{hm}^{3}$, but landslides processes in the right buttress of the dam together with waterproofing problems in the reservoir provide a real maximum storage of $33 \mathrm{hm}^{3}$. The maximum level of storage allowed is limited to $345 \mathrm{~m}$ a.s.l. due to a landslide in the right buttress of dam. Raising the level of the reservoir could annul the overflow channel and put in risk the dam.
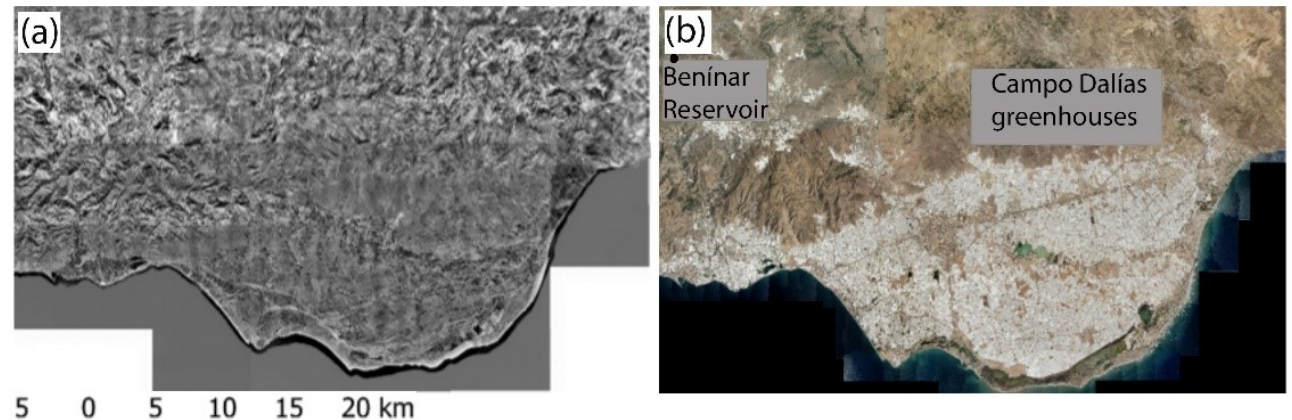

Fig. 2. Evolution of greenhouses extension from 1956 (a) (0 ha) to 2017 (b) (21.285 ha).

Beninar dam also supplies water to the greenhouses of Campo de Dalias, the main industry of west Almeria (Figure 2) that demands around $140 \mathrm{hm}^{3}$ of water annually [17]. 
The maximum annual water supply of Beninar throughout its history was $29 \mathrm{hm}^{3}$ in 2011 , that represents a $20 \%$ of the total greenhouses demand. The continuous extractions of the aquifer favoured its salinization, that obliged to declare it officially overexploited in two times, 1986 and 1996.

\section{Methods}

This study is based on the analysis of the effects of erosive and sedimentation processes in Adra river basin and their impact on the loss of storage of Beninar reservoir and its consequences.

\subsection{Assessment of soil loss and fluvial contributions}

The bedload and suspended load sediment transport stored at the entrance of reservoir are analyzed in order to distinguish delta deposition events. The ratio of shear to fall velocities $\mathrm{u}^{*} / \omega$ is used as an indicator of the domination of suspension over bedload modes. Suspended load is dominant when $\mathrm{u}^{*} / \omega>2$ [18]. The shear velocity is defined as $u^{*}=\sqrt{g * R_{h} * S}$ where $g$ is the gravity $g=9.8 \mathrm{~m} \mathrm{~s}^{-2}, R_{h}$ is the hydraulic radius, and $S$ is the local slope, and the settling velocity $\omega$ is defined by:

$$
\omega=\frac{12 v_{m}}{d_{m} C_{D}}\left[\left(1+\frac{C_{D} d_{*}^{3}}{108}\right)^{0.5}-1\right]
$$

where $C_{D}=0.168$ is the drag coefficient, $v_{m}=1.01 \cdot 10^{-6} \mathrm{~m}^{2} \mathrm{~s}^{-1}$ is the kinematic viscosity of water at $20^{\circ} \mathrm{C}$ and $\mathrm{d} *$ is the dimensionless diameter given by $d_{*}=$ $d_{m}\left[(G-1) g / v_{m}^{2}\right]^{1 / 3}$ and $G$ is the specific gravity, $G=\rho_{s} / \rho$, where $\rho_{s}$ is the mass density of the solid particles, $\left(\rho_{s}=2650 \mathrm{~kg} \mathrm{~m}^{-3}\right), \rho$ is the water density $\left(\rho=1000 \mathrm{~kg} \mathrm{~m}^{-3}\right)$.

Rickenmann [19] proposed the following equation for $0.04 \% \leq S \leq 20 \%$ :

$$
Q_{b}=1.5\left(Q-Q_{c}\right) S^{1.5}
$$

here $Q_{b}$ is the bedload transport rate over the entire channel width, $Q$ is the discharge, $Q_{c}$ the critical discharge for the initiation of transport.

Moreover, immature debris flow conditions have been studied by means of the equation proposed by Takahashi [20]:

under the $\tau *$ range

$$
Q_{b}=\frac{2}{3} \frac{\left(4.2-0.3 c_{*}\right)}{\cos ^{2} \theta(\tan \varnothing-\tan \theta)^{2}} \tau_{*}^{2.5} u_{*} d_{s} B
$$

$$
\tau_{*} \geq \cos \theta\left\{\left(c_{*}+\frac{q_{s}^{*}}{8.5}\right)(\tan \varnothing-\tan \theta)-\frac{\rho_{s}-\rho}{\rho} \tan \theta\right\}
$$

where $c *$ is the maximum concentration of the grains, $\theta$ is the slope angle (degrees), $\phi$ is the internal friction angle (degrees), $d_{s}$ is the particle size $(\mathrm{m}), \tau *$ is the dimensionless shear stress, $\tau_{*}=u *^{2} /\left[\left(\rho_{s} / \rho-1\right) g d_{s}\right]$, B is the channel width (m), and $q_{b}{ }^{*}$ is the dimensionless bedload transport rate, $q_{b}{ }^{*}=q_{b} \tau *{ }^{0.5}\left(u * d_{s}\right)^{-1}$, with $q_{b}$ the sediment discharge per unit width $\left(\mathrm{m}^{2}{ }_{\text {sed }} \mathrm{s}^{-1}\right)$. Values of $c^{*}=0.65, \tan \phi=0.8$ are assumed in this work based on the experimental data of Takahashi [21] and Mizuyama [22].

\subsection{Sedimentation patterns at the reservoir}

Bathymetric and topographic measurements of Beninar reservoir were carried out for the first time in July 2015 since its start-up in November 1983. The bathymetric surveys the submerged area $(60,65 \mathrm{ha})$ of the reservoir were done with an Imagenex multibeam echosounder with data correction for heading, depth, pitch, heave and roll. The topographic works at the delta deposits were performed using differential GPS. These 
results were compared with a bathymetry measured just after the construction of the reservoir.

Five sediment samples were taken manually in 2015 upstream along the river. The sediment was characterized through the mean values of $d_{s}$ and $f_{s}$ of the different samples obtained (Table 2). Among other properties, the mean density of sediment was estimated in $1,43 \mathrm{~g} \cdot \mathrm{cm}^{-1}$.

Table 2. Mean and variances values of $d_{s}$ and $f_{s}$

\begin{tabular}{|c|c|c|c|c|c|c|c|c|c|}
\hline ds & $\boldsymbol{d 1 0}$ & $\boldsymbol{d 2 0}$ & $\boldsymbol{d 3 0}$ & $\boldsymbol{d 4 0}$ & $\boldsymbol{d 5 0}$ & $\boldsymbol{d 6 0}$ & $\boldsymbol{d 7 0}$ & $\boldsymbol{d 8 0}$ & $\boldsymbol{d 9 0}$ \\
\hline Mean & 0.455 & 0.819 & 1.247 & 1.675 & 2.224 & 3.210 & 4.850 & 7.522 & 12.810 \\
\hline Variance & 0.043 & 0.227 & 0.706 & 1.303 & 2.135 & 3.192 & 5.498 & 11.763 & 37.410 \\
\hline fs & $\boldsymbol{f 1 0}$ & $\boldsymbol{f 2 0}$ & $\boldsymbol{f 3 0}$ & $\boldsymbol{f 4 0}$ & $\boldsymbol{f 5 0}$ & $\boldsymbol{f 6 0}$ & $\boldsymbol{f 7 0}$ & $\boldsymbol{f 8 0}$ & $\boldsymbol{f} \mathbf{5 0}$ \\
\hline Mean & 0.091 & 0.106 & 0.102 & 0.127 & 0.104 & 0.120 & 0.119 & 0.107 & 0.123 \\
\hline Variance & 0.00079 & 0.00049 & 0.00217 & 0.00069 & 0.00039 & 0.00018 & 0.00016 & 0.00024 & 0.00077 \\
\hline
\end{tabular}

\subsection{Estimation of the useful life of the reservoir}

The useful life of a reservoir in terms of its operativity is defined as the expected time at which the reservoir will be completely filled with sediments [18]. It has been calculated as the superposition of the components due to fluvial processes and hillslope contributions, being defined by:

$$
T_{R}=\frac{V_{R} \cdot \gamma_{m d T}}{\left(\sum_{i} \Delta p_{i} \cdot Q_{t i}\right)+\left(\sum_{i} T_{E i} \cdot Q_{t i}\right)}
$$

where $V_{R}$ is the storage capacity or volume of the reservoir, $Q_{t}$ is the mean annual incoming total sediment discharge in weight per year, $\Delta p_{i}$ is the sediment size distribution, $T_{E}$ is the trap efficiency of the reservoir, defined in this work by the approaches proposed by Brown [23], Heinemann [24] and USDA-SCS [25] and $\gamma_{m d T}$ is the dry specific weight of sediment deposits after $T$ years.

Many works have addressed the large spatial and temporal variability of the specific weight, $W_{d}$, in reservoirs $[26,27]$. To consider the consolidation effect of the sediment the expression proposed by Miller [28] was used:

$$
W_{d}=W_{1}+0.4343 K\left[\frac{t}{t-1} \log (t)-1\right]
$$

where $W_{d}$ is the average dry specific weight of the deposit $\left(\mathrm{kg} \mathrm{m}^{-3}\right), t$ is the consolidation period in years, $W_{l}$ is the initial sediment specific weight in the first year $\left(\mathrm{kg} \mathrm{m}^{-3}\right)$ and $K$ a consolidation constant. The values of $W_{l}$ and $K$ can be estimated from the equation proposed by Lara and Pemberton [29].

\subsection{Downstream impact analysis}

An analysis of the capacity of regulation available have also been done by taking into consideration structural problems of the dam and landslides processes in the right buttress of the dam, and the current volume of dead storage due to sedimentation processes in the bottom-set of the reservoir since its start-up.

Regarding the capacity of flooding regulation, the level of evacuation point has been determined, taking into consideration that the overflow channel cannot be used due to the limitation maximum level of exploitation of Beninar reservoir. It has been also calculated the current level of sediment in the bottom-set. Through these two variables the volume available for flooding regulation were calculated and the capacity of evacuation of basinfloor drainages in case of extreme events. 
On the other hand, the loss of water volume to satisfy the water demands of greenhouses downstream was estimated from 1) the demands of greenhouses and the water supply of Beninar reservoir, 2) the volume available to mix and improve the quality of the water have been determined and 3) the life expectancy of the reservoir.

\section{Results and discussion}

Fig. 3 (a) shows the frequencies of values of $u^{*} / \omega$ along the whole period of the study. As can be observed, the most representative mode of transport varies between 0.5 and 2, indicating that the main mode of transport is the mixed load, which, for the existing granulometry, confirms the occurrence of debris flow processes.

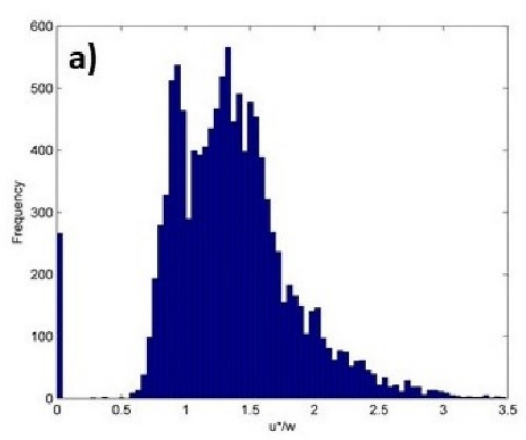

b)

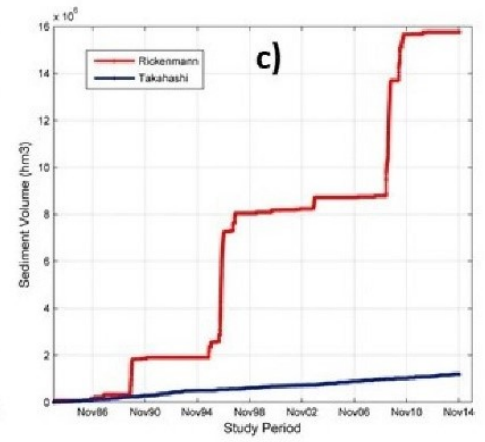

1984-2015

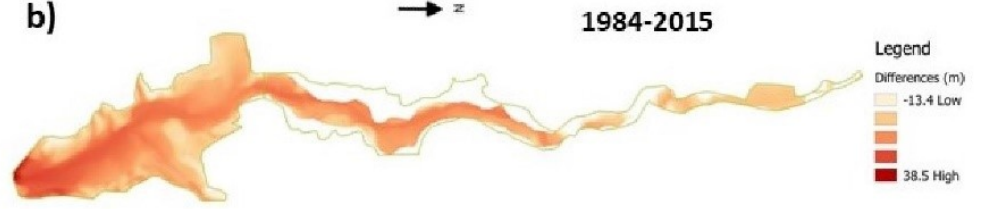

Fig.3. Modes of transport histogram (a), differences between bathymetric and topographic measures (b) and fluvial transport modelling results (c).

Specific models for torrential rivers were applied to estimate the volume of sediments in the reservoir (Fig. 3(c)). The use of the formula of Rickenmann [19] overestimates the value of fluvial contributions to $15,7 \mathrm{hm}^{3}$. The model of Takahashi [20] that analyzes the transport processes in immature debris flow conditions gave an estimated volume of sediments by fluvial contributions of $1,19 \mathrm{hm}^{3}$ that were close to the real volume measured in at the reservoir delta $\left(1,68 \mathrm{hm}^{3}\right)$.

The storage capacity of the Beninar reservoir has undergone important changes during the study period. The estimated net accumulated sediment during the study period has meant an estimated volume loss of $10 \%$ of the original reservoir capacity, and of $20,6 \%$ considering the maximum allowed reservoir capacity. In Fig. 3(b), the differences between the topographic and bathymetric surfaces are shown. The entire life of the Beninar reservoir shows a total volume of sediments of $6,8 \mathrm{hm}^{3}$, being $1,68 \mathrm{hm}^{3}$ the volume of sediment estimated as fluvial contributions, and $5,14 \mathrm{hm}^{3}$ as hillslope contributions. The total fraction of fluvial contributions represented the $25 \%$ of the total sediment trapped at the reservoir.

Values of $T E_{B R}=96.57 \%, T E_{H E}=94.47 \%$ and $T E_{U S}=96.71 \%$ were obtain from the expressions [23-25] respectively. For this study, a constant value of $T_{E}=95.91 \%$ was considered. This value is consistent with the morphology of the reservoir, the interoperability performed and the area from which water discharge occurs. Specific 
weight estimation for the submerged sediment at Beninar reservoir ( $\mathrm{t}=32$ years) was also calculated with values of $W_{l}=1249.34 \mathrm{~kg} \mathrm{~m}^{-3}, K=49.6 \mathrm{~kg} \mathrm{~m}^{-3}$ and $W_{d}=1261.27 \mathrm{~kg} \mathrm{~m}^{-3}$. To this end, the reservoir has been subdivided into the bottom-set, associated with suspended sediment deposits, and the delta, linked to fluvial deposits.

Considering the operational volume of the reservoir, a life expectancy of 42 years was obtained due to hillslope processes. Adding fluvial contributions, the life expectancy was reduced to 38 years. Taking into account that the sediment trapped in the reservoir seems to be due to three single intense pulses of a few hours that represents a $20 \%$ of volume loss of its total capacity, the use of common formulations of fluvial contributions seems to introduce high uncertainty in the estimation of the useful life of reservoirs with these characteristics.

Flood abatement capacity is one of the problems derived from the loss of reservoir storage by sedimentation. Beninar dam cannot use the overflow channel to evacuate extreme events due to its level of exploitation, being the basin-floor drainage the only way of evacuation. The current level of sediments has reduced $58 \%$ the capacity of evacuation of this basin-floor drainage, which is equivalent to $2 \mathrm{hm}^{3}$ of its current capacity of regulation.

If only three intense events of precipitation have represented a $20 \%$ of volume loss of its total capacity, new intense events would extremely increase the loss of capacity of the reservoir, especially considering the predictions made from the IPCC climate change scenarios, that includes increases in the severity of events along the Mediterranean areas.

\section{Conclusions}

This work brings to light the effects that siltation of Beninar reservoir would affect downstream from two different perspectives. Bathymetric and topographic measures gave a total volume of sediment of $6,8 \mathrm{hm}^{3}$ accumulates along the 32 years of life of the reservoir. This works highlights two different component of sedimentation processes, fluvial and hillslope contributions in a relation of $25 / 75$. The torrential nature of Adra river basin has produced the $20 \%$ of volume loss of Beninar reservoir just during three intense pulses of a few hours duration. The uncertainty of fluvial processes and the increases the events severity along the Mediterranean areas predicted by the IPCC climate change, would reduce considerably Beninar reservoir useful life.

The impact downstream of sedimentation processes can be analyzed from two different perspectives, namely, the loss of regulation capacity of floodings, limited to only $2 \mathrm{hm}^{3}$, that increases the risk of damages to the population and the shortage of water for the irrigation.

The Beninar reservoir was also built to satisfy the high-water demand of Campo de Dalias greenhouses, avoiding extractions of its overexploited and salinized aquifer. However, structural problems of the dam and the landslides processes in the right buttress of the dam, greatly limits water storage, which have hampered to achieve its goal. Fresh water contributions from the watershed also allowed farmers reducing chemical components to achieve an adequate value of conductivity. Other resources such as desalinized water from the sea would be used from greenhouses demand in case of null Beninar water supply. These perspectives threaten directly the viability of greenhouse cultivation at the study area with a rise in the water price. These results agree with the work by Downward and Taylor's [30], who reported that the water supply capacity in the region of Almería was not sustainable for the horticultural production system.

The first author of this research would like to acknowledge the support of the Ministry of Environment and Zoning of Andalusian Regional Government. The authors would like to 
acknowledge the support of the AQUACLEW project (Advancing QUAlity of CLimate services for European Water) co-funding from the European Commission (Grant Agreement 690462).

\section{References}

1. G.M. Kondolf, G.M. Earth's Future, 2, 256-280. (2014)

2. ICOLD. $19^{\text {th }}$ Congress on Large Dams. q. 74a (1997)

3. G.W. Annandale. Quenching the Thirst: Sustainable Water Supply and Climate Change (CreateSpace, North Charleston, S.C., 2013)

4. R. Coppus, A.C. Imeson. Earth Surf. Proc. and Landf. 27(13); 1365-1375 (2002)

5. D.M. Powell, I. Reid, J.B. Laronne. Water Resour. Res. 37(5):1463-1474 (2001)

6. A. Millares, M.J. Polo, A. Moñino, J. Herrero, M.A. Losada. Geomorphology. 206:330-342 (2014).

7. J.M. Turowski, D. Rickenmann, S.J. Dadson. Sedimentology 57(4):1126-1146 (2010)

8. Consejería de Agricultura, Pesca y Desarrollo Rural. Cartografía de Invernaderos en Almería, Granada y Málaga (Spain, 2017)

9. J. de Miguel, J.G. López, R. Baeza. IDAWC/pr11-129 (2011)

10. G. Castejón, A. Romero. Rev. Bibl. Geog y CC.SS. Univ. Barcelona v.XIX,1102 (2014)

11. M.A. Losada, A Baquerizo, M. Ortega-Sánchez, A. Ávila. Jour. Coast. Res. 59, 218 $228(2011)$

12. A. Félix, A. Baquerizo, J.M. Santiago, M.A. Losada. Jour. Environ. Manag. 112, 252$266(2012)$

13. R.J. Bergillos, C. Rodríguez-Delgado, A. Millares, M. Ortega-Sánchez, M.A. Losada. Water Resour. Res., 52, doi: 10.1002/2015WR018395 (2016)

14. K.G. Renard, G.R. Foster, G.A. Weesies, D.K. McCool, D.C. Yoder. A guide to conservation planning with the Revised Universal Soil Loss Equation (RUSLE). Agriculture Handbook, vol. 703. (US Department of Agriculture, Washington, DC, 1997)

15. D.G. Medio Natural y Política Forestal. Inventario Nacional de Suelos: Almería y Granada. Ministerio de Medio Ambiente Rural y Marino, Madrid (2007)

16. E. Carrasco, J. López, M. Vizcaino. Rev. OO.PP. abril-mayo pp. 233-250 (1982)

17. Instituto Geológico y Minero de España. Resultados del Proyecto sobre conocimientos alcanzados de los Acuiferos del sur de Sierra de Gádor-Campo de Dalías. (Ministerio de Ciencia y Tecnología, 2003)

18. P.Y. Julien. Erosion and Sedimentation, $2^{\text {nd }}$ edition. (Cambridge University Press, 2010)

19. D. Rickenmann, Water Resour. Res. 37(12):3295-3305 (2001)

20. T. Takahashi, Proc. $22^{\text {nd }}$ IAHR Congress, Fluvial Hydraulics, Lausanne (1987)

21. T. Takahashi, Study on deposition of debris flows (3), Kioto Univ, 327-348 (1982)

22. T. Mizuyama, IAHS Pub. 212-224 (1981)

23. C.B. Brown, Proc. Amer. Soc. Civ. Eng. 69, 1493-1500 (1943)

24. H.G. Heinemann, J. Amer. Water Resour. Ass. 17, 825-830 (1981)

25. USDA-SCS. National engineering handbook (2 ${ }^{\text {nd }}$ edn). (US Dep.Agriculture, WA, 1983)

26. J. Salas, H. Shin, J. Hyd. Eng. 125, 339-350 (1999)

27. G. Verstraeten, J. Poesen, Earth Surf. Proc. \& Landf. 26, 375-394 (2001)

28. C.R. Miller, Determination of the unit weight of sediment for use in sediment volume computations (Bureau of Reclamation, Denver, 1953)

29. J.M. Lara, E.L. Pemberton, Proc. Fed. Interagency Sedimen. Conf. pp.818-845 (1965)

30. S.R. Downward, R. Taylor, J. Environ. Manag. 82, 277-289 (2007) 